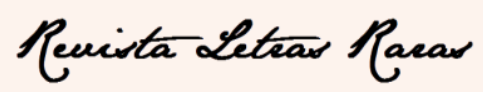

ISSN: 2317-2347 - v. 8, n. 3 (2019)

\title{
O músico da madrugada
}

José Amâncio*

Recebido em 09 jun. 2019. Aprovado em 18 ago. 2019.

No arcabouço velho e dorido, o trauma é uivante! Num átimo absurdo e de imensurável impacto, Clement Äauster acordou aos urros, esperneando-se, rasgando sua camiseta de dormir, enquanto rolava na cama! Saltou de semblante rubente, agitadíssimo e trêmulo, na madrugada fria daquele Janeiro de 1945. Seu tórax ia explodir sob os muitos e acelerados batimentos cardíacos. Terror enceguecido sentia, e uma presença carregadíssima circulava ao seu redor. Ofegante, ele corria de um canto a outro do quarto, derrubando o abajur, o criado mundo, os livros e sua Luger — seus olhos eram dois bugalhos brancos; suas mãos, um cismo caótico e sem direção, como se relutassem contra duas amarras de fantoche que insistiam sobre ele. Após meia hora de incontida agitação, Clement assentou-se na cama, exausto e encharcado pelos suores. Estava mais calmo, todavia jamais iria esquecer-se do que vivenciara, entre o sonho e o terror, e a realidade. Ali, ele sondava o quarto com olhos tontos, esvanecidos pelo horror vacui que acampa no vão da alma, após terrível susto. Tamanha era a penumbra da noite que nenhum som se ouvia, a não ser a perturbação dos próprios ouvidos zumbindo. Não era a primeira vez que aquele mal o acometia, nem seria a última vez que seria visitado, certamente. Ora, Clement sabia que iria enlouquecer.

Tudo começou em agosto de 1942, quando dos primeiros testes com o AGON, fruto do Projeto Narciso. Para uma compreensão possível, todavia resumitiva do AGON, é preciso visualizá-lo numa representação de maquinaria tecnológica de 8 metros de altura, em lataria fosca, de um cinza escuro profundo, repleto de cilindros, chavetas, exaustores e pinos, em cujo funcionamento elétrico blecautearia facilmente uma cidade de 3 ou 4 mil habitantes, e isto fora o ocorrido no primeiro teste. O Projeto

\footnotetext{
${ }^{*}$ Mestre em Ecologia Humana pelo Programa de Pós-Graduação em Ecologia Humana no Campus VIII da Universidade Estadual da Bahia (PPGEcoH/UNEB); Docente na Universidade Federal de Alagoas UFAL, Brasil; wellington.silva@ @edu.ufal.br.
} 


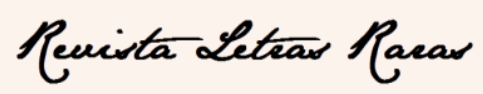

ISSN: 2317-2347 - v. 8, n. 3 (2019)

Narciso era bancado pelo Regime e iniciara-se em 1939 em completo sigilo - Clement era o especialista responsável. Segundo a finalidade daquele projeto, o AGON tinha uma função específica: restaurar mimeticamente a estrutura cerebral e, sobretudo resgatar a essencialidade da "mente póstuma" de importantes falecidos ${ }^{1}$ - e comprovou-se experimentalmente que sua eficiência era plena, efetiva e extensiva!

A invenção e a descoberta de suas possibilidades eram imensuráveis. Foi um sucesso, em suas propostas iniciais, para aquilo que, a partir dos resultados obtidos, abrir-se-ia em promessas de aplicabilidade à nova ordem de mundo insurgente. Contudo, para o seu pleno sucesso, (sem prescindir de efeitos menos consistentes, todavia intrigantes, segundo à medida da distância no tempo do seu objeto de análise e de arqueomnemose - a mente de alguém falecido evocada) era preciso utilizar-se, como plataforma, do vão do crânio recém-extraído da pessoa cuja mente seria mimetizada, e por meio de complexas técnicas de metarressonância em diversos níveis, a saber, o nível suprapercussivo, o intraimagético, o pneuma-imanente, o submnemônico, o transmnemônico, o irradiativo, o suprassondante, o supraconsonante, o intraespecular, o arco-simulopreteritivo, o plasmático, o agon-emersivo, o extramnemônico, o intraestrutural in convexus e o parapsicoefusivo, entre outros processos menos compreensíveis e mais minuciosos, sobretudo dificílimos de denominar e explicar. O AGON trouxe ao mundo, num recipiente fulgurante AIP (em verde translucido) a mente mnemônica de um gênio musical - a memória hipermentalizada do violoncelista Anton Hausmman (1823-1901) — e esta fora resgatada pela admiração profunda do doutor Clement Äauster ao violoncelista. Ora, o doutor Clement Äauster era um aspirante à concertista e à compositor contrapontista, embora executasse a maioria das suas músicas, em seu violoncelo, de modo demasiadamente comum. No caso do finado Anton Hausmman, para que merecidamente seja relembrado aqui, fora o maior entre os maiores e o mais prolixo violoncelista, concertista e compositor da sua época, e talvez de todo o século XIX, deixando um riquíssimo legado, no que diz respeito à complexidade da arte do contraponto, por meio de elaborações de figuras sonoras de extrema complexidade e

\footnotetext{
${ }^{1}$ A mente é muito mais do que se pensa, em densidade e extensão. Todas a conjunções e confluências históricas do ser que pensa, pondera e tem memória, constituem-se em Mente, e esta transcende o cérebro e está em todo lugar, ligada aos eventos destes lugares, bem como reverbera no arcabouço oco da caveira, mesmo que exista em sua forma branca e óssea.
} 


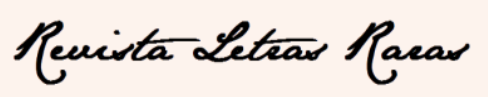

ISSN: $2317-2347$ - v. 8, n. 3 (2019)

fina beleza, sedimentadas e ligadas entre si, em toda a sua obra, como num conjunto único e expressivo. E ainda, ao que alude à revolução das extensões e da densidade das formas musicais, e dos meios orquestrais para a sua realização, conhecidos em sua época, Hausmman fora um gênio revolucionário. Por exemplo, no intuito da composição da sua décima primeira sinfonia, Hausmman utilizou-se de uma partitura encomendada de 96 pentagramas. Cabe-nos lembrar que seus feitos musicais foram tão amplos que somente a partir da década de trinta fora em parte compreendidos Clemente era um dos pioneiros quanto a este reconhecimento e divulgação, escrevendo, aliás, uma dezena de artigos, um livro avolumando sobre a obra do seu mestre, e ainda conservando o violoncelo de estimação de Hausmman, um Guarneri de Cremona, de 1645 .

No entanto, segundo certas fontes, Anton Hausmman foi um homem demasiadamente azarado, especialmente porque não fora reconhecido: viveu toda uma vida de penúria e quase ostracismo; foi judeu culturalmente convicto, todavia intelectualmente moderno ao modo tcheco, e por ser judeu e tcheco a um só tempo, fora um desencontrado social e existencialmente em Viena onde vivia. Fora perseguido insistentemente por muitos desafetos, anônimos em sua maioria. Diversas vezes caluniado e acusado de antipatriotismo, esteve em situações vexaminosas e exaustivas, jutos às autoridades. Perdera a esposa e o primogênito num parto mal sucedido - o que para alguns historiadores tratou-se de uma sabotagem. Desenganado, nunca mais casouse e nunca mais compôs. Morreu emostracismo, e fora enterrado numa vala comum. Diante deste panorama existencial, o doutor Clement Äauster sabia que ali (dentro de um recipiente fulgurante AIP — em verde translucido) pairava a mais densa e inquietante genialidade do século passado. O que mais instigava o doutor era a possibilidade de resgate de alguma obra inédita do seu mestre.

$\mathrm{O}$ recipiente AIP era uma espécie de câmara hermética ativa, mantida por uma fonte de 157 volts, em corrente contínua, com uma abertura de 8 milímetros (em cujo centro acendia um micropino de ponta oval), num vão inferior devidamente elaborado no formato de elmo para encaixe craniano do receptor, que antes sofreria uma incisão craniana de 8 milímetros, entre os dois lobos frontais, na intenção de uma abertura por meio da qual o conteúdo etérico do recipiente AIP seria aplicado. 


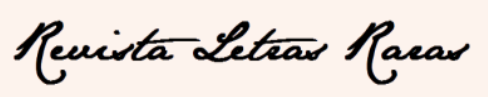

ISSN: $2317-2347$ - v. 8, n. 3 (2019)

O objetivo do doutor Clement Äauster era acessar e fazer subsumir em própria mente - por transferência plasmática encéfalo-absorvitiva - a mente criativa de mestre Hausmman, no intuito único e revolucionário de expandir a sua própria genialidade, e isso de fato ocorreu com amplo e efetivo sucesso, em 28 de março de 1943 — o doutor Clement Äauster possuía em sua mente a vida mental de Hausmman, em $98,5 \%$ da sua totalidade vivida, de tal modo que parecia experimentar em cores, sabores, olfatos, sons e tatos, aquela vida pregressa.

E como primeiro resultado deste feito revolucionário, aquilatou-se o desempenho sobre o violoncelo - a intuição iluminada e a certeza técnica, a abrupta aquisição do tato sensibilíssimo necessário sobre as cordas, o pleno domínio da geografia fina sobre o espelho do violoncelo, da lucidez e da sofisticada escolha do repertório, de considerações e ponderações sobre os aspectos únicos da experiência do timbre, do instrumento, da afinação, das cordas, da postura, da plateia - porque era o próprio Anton Hausmman que com ele executava as duas Suítes para Violoncelo de Bach à audiência arrebatada (e também Hausmman recebia os aplausos, por assim dizer).

Em pouco tempo compôs músicas de câmara para trio, quarteto e quinteto, além de alguns Lieder, um Belo Réquiem e um poema Sinfônico denominado "Alma Stella", porque era o próprio Hausmman que com ele trabalhava. Revisou e ampliou — nos vários aspectos dos termos "revisar" e "ampliar" —, um concerto inédito para violoncelo e a sua primeira sinfonia - porque com ele o próprio Hausmman compunha.

Apesar das áureas iniciais, todavia, de súbito fora tomado aos poucos por um mal incomum e sempre crescente, quanto mais aprofundadamente submergia na memória de Hausmman que possuída dentro de si. Os pesadelos de Janeiro de 1945 eram mais que um efeito colateral desse aprofundamento - era talvez a presentificação de uma vida passada vivida na vida do doutor Clement, como revisite de um espectro sombrio, do tamanho do universo mental e da memória de um morto, operando na mente de um vivente.

A inveja é uma admiração angustiada. Após janeiro do mesmo ano, especificamente em 08 de julho, o doutor Clement Äauster fora transferido, quase demente, ao Sanatório de São Bartolomeu, na Pomerânia, acometido por sustos, surtos esquizofrênicos e ataques epiléticos incontroláveis por quaisquer vias medicamentosas. Seu quadro era bizarro ou mórbido (como queira) para o saber da época, e ele, quando 


\section{Pevista Leteas Paras}

ISSN: $2317-2347$ - v. 8, n. 3 (2019)

aparentemente estabilizado, apresentava em suas orbitas um terror difuso. Acordava em sustos absurdos e de imensurável impacto, aos urros, esperneando-se com força e rapidez, enquanto rolava na cama.

Improvidente, o doutor Clement Äauster nunca levara em consideração que ele mesmo era também o Hausmman ressurreto, em vida mental. E a manifestação mais cruel da presença de Hausmman em sua mente e em sua vida era a terrível memória do filho de Hausmman abortado em suas mãos, como seu fosse seu próprio filho, e era seu filho! Tal era dor mais pungentemente e desconhecida - e esta dor imensa sobrevinhalhe de dentro do seu pequeno cerne do cientista, que nunca tivera filho. E a dor de perder o filho que nunca teve o visitava como um uivo fantasmagórico, que estourava em pânico e em sustos; acometia-o como um desgosto que não conhecia de fato, mas experimentava de todo, como uma angústia alimentada por fatos que não vivenciara, todavia conhecia-os. Por fim morreu dois meses depois acometido por tuberculose crônica que não possuía. Morreu de uma tristeza profunda e inerente que não era deveras sua. Morreu por causa dos efeitos de sífilis que não a sua. 